\title{
Alkyl Xylosides: Physico-Chemical Properties and Influence on Environmental Bacteria Cells
}

\author{
Wojciech Smułek $^{1} \cdot$ Ewa Kaczorek $^{1} \cdot$ Zuzana Hricovíniová $^{2}$
}

Received: 15 November 2016/Accepted: 18 August 2017/Published online: 1 September 2017

(C) The Author(s) 2017. This article is an open access publication

\begin{abstract}
A group of four selected non-ionic surfactants based on carbohydrates, namely octyl D-xyloside $\left(\mathrm{C}_{8} \mathrm{X}\right)$, nonyl D-xyloside $\left(\mathrm{C}_{9} \mathrm{X}\right)$, decyl D-xyloside $\left(\mathrm{C}_{10} \mathrm{X}\right)$ and dodecyl D-xyloside $\left(\mathrm{C}_{12} \mathrm{X}\right)$, have been investigated to accomplish a better understanding of their physico-chemical properties as well as biological activities. The surfaceactive properties, such as critical micelle concentration (CMC), emulsion and foam stability, the impact of the compounds on cell surface hydrophobicity and cell membrane permeability together with their toxicity on the selected bacterial strains have been determined as well. The studied group of surfactants showed high surface-active properties allowing a decrease in the surface tension to values below $25 \mathrm{mN} \mathrm{m}^{-1}$ for dodecyl D-xyloside at the CMC. The investigated compounds did not have any toxic influence on two Pseudomonas bacterial strains at concentrations below $25 \mathrm{mg} \mathrm{L}^{-1}$. The studied long-chain alkyl xylosides influenced both the cell inner membrane permeability and the cell surface hydrophobicity. Furthermore, the alkyl chain length, as well as the surfactant concentration, had a significant impact on the modifications of the cell surface properties. The tested non-ionic surfactants exhibited strong surface-active properties accompanied by the significant influence on growth and properties of Pseudomonas bacteria cells.
\end{abstract}

Wojciech Smułek

wojciech.smulek@doctorate.put.poznan.pl

1 Institute of Chemical Technology and Engineering, Poznan University of Technology, Berdychowo 4, 60-965 Poznan, Poland

2 Institute of Chemistry, Slovak Academy of Sciences, Dúbravská cesta 9, 84538 Bratislava, Slovakia
Keywords Foaming properties $\cdot$ Microbiology $\cdot$ Non-ionic surfactants $\cdot$ Surface activity

\section{Introduction}

Surfactants of natural origin are gaining ever-growing interest because of their great potential driven by a strong demand for biodegradable products. They have attracted increasing attention as they are ecologically suitable alternatives to their synthetic counterparts derived from petrochemical resources. Sugar-based amphiphiles-alkyl glycosides are intensively studied compounds due to their widespread applications in various fields [1,2].

Long-chain alkyl glycosides belong to the group of nonionic surfactants. These amphiphilic compounds contain hydrophilic and hydrophobic regions of the molecule, which allow them to accumulate between fluid phases and reduce the surface and interfacial tensions as well [3]. Besides their excellent surfactant properties, their low toxicity and good biodegradability are important advantages. Moreover, they can be produced from renewable sources, which makes them environmentally friendly chemicals. Additionally, their synthesis fulfills requirements of green chemistry principles, such as the use of safe solvents and substrates and high energy efficiency [4]. Moreover, the alkyl derivatives of carbohydrates can enable formulation of stable and useful emulsions and microemulsions [5]. Hence, the alkyl derivatives of saccharides have a variety of uses in the food industry and in the production of cosmetics and detergents [6, 7]. Mildness and protection for the skin as well as high-quality standards by minimization of by-products and trace impurities make the alkyl polyglucosides preferred components of personal care products [5]. The utilization of surfactants from 
natural sources in the medical field has increased significantly during the past decade [2]. The alkyl derivatives of carbohydrates are recognized as valuable parts of drugdelivery systems, which generate no harmful derivatives in the human organism [8]. Additionally, these surfactants are considered to be very promising agents in bioremediation, with recent examples in surfactant-enhanced biodegradation of hydrophobic pollutants [9], phytoremediation of polycyclic aromatic hydrocarbons [10] and washing of crude oil contaminated soils [11].

Hemicelluloses are the second most abundant polysaccharides occurring in nature. These essentially linear polymers with short-branched chains can be easily hydrolyzed to monomeric sugars. One of the main components of hemicelluloses is xylan. Its molecule has a backbone with 1,4-linked $\beta$-D-xylopyranose units (xylose), hence can be an efficient source of this monosaccharide [12].

The methods of synthesis of alkyl derivatives of xylose include enzymatic reactions $[12,13]$ as well as a one-pot process with sulfuric acid as catalyst [14]. Sekine et al. [15] presented their synthesis using ionic liquids. Additionally, Ludot et al. [16] used sulfoxides and sulfones as solvents in a non-catalyst process. Recently, Hricovíniová has described a microwave-assisted, transition-metal catalyzed glycosylation for the preparation of various amphiphilic alkyl glycosides [17, 18].

The physical and chemical properties of the surfactants depend strongly on the alkyl chain length. The critical micelle concentration (CMC) of cationic surfactants is proportional to the hydrophobic chain length and varies with the carbon number in the alkyl chain [19]. Additionally, with an increasing number of carbon atoms in the alkyl chain, the surface area occupied by the surfactant molecule on interphase surface increases [20]. Moreover, the alkyl chain length of a surfactant can affect its foaming properties [21]. The lengthening of the alkyl-chain enhances the surface activity of zwitterionic imidazoliumbased surfactants [22]. The interfacial dilational properties of several hydroxy-substituted alkyl benzenesulfonates with different alkyl chain lengths were tested by $\mathrm{Wu}$ et al. [23]. The correlation between alkyl chain lengths and the surface active properties was also described in the case of choline carboxylate soaps [24], sodium- $N$-acyl sarcosinate (SNAS) and $N$-cetylpyridinium chloride (CPC) surfactants [25] as well as sophorolipids produced by Candida bombicola [26].

The influence of alkyl chain length on surfactant properties also refers to alkyl derivatives of carbohydrates. The change of the surface properties depends on the alkyl length and the hydrophilic carbohydrate headgroup size among $n$-alkyl- $O$-melibiosides and $n$-alkyl- $O$-cellobiosides [27]. Similarly, the properties of alkyl maltosides and glucosides have also been described in the literature
[28, 29]. For example, the wide review of alkyl glucosides properties and applications was prepared by von Rybinski and Hill [5].

Thinking about an extensive use of surfactants, their influence on ecosystems should be investigated. Surfactants are ubiquitous pollutants present in wastewaters and soils [30]. Hence, their impact on the environment is of great interest [31]. One of the research areas is the influence of surfactants on environmental bacteria. Apart from direct toxicity on microorganisms, surface active agents can modify cell membrane permeability [32], zeta potential of cell surfaces [9] and bacterial adhesion to organic or solid phases [33, 34]. The environmental effect of surfactants is also connected with their alkyl chain length [35]. It also refers to cell surface properties [36].

The aim of the research was the investigation of physical and chemical properties and the evaluation of the structure-property relationship of four alkyl D-xylosides varying in chain length. The dependency between surface tension and surfactant concentration was analyzed in order to evaluate the critical micelle concentration (CMC) of alkyl xylosides, as well as their emulsification properties and foam stability. The second part of the research was aimed at identifying the impact of the studied compounds on bacterial cells from the Pseudomonas genus, found frequently in the environment. The toxicity effect of the surfactants was determined as well as changes of cell surface hydrophobicity and cell membrane permeability. The study will provide a broad insight into surface active properties of alkyl xylosides. Moreover, it will allow an assessment of the potential environmental risk related to with their contact with microorganisms.

\section{Materials and Methods}

\section{Chemicals}

All fine chemicals employed in this study were of highest purity grade, produced by Sigma-Aldrich (Germany). Conversions, purities and structure of products were determined by NMR spectroscopy. High-resolution NMR spectra were recorded in a $5 \mathrm{~mm}$ cryoprobe on a Bruker Avance III HD spectrometer at 14T. The experiments were carried out at $25{ }^{\circ} \mathrm{C}$ in chloroform- $\mathrm{d}_{6}\left(\mathrm{CDCl}_{3}\right)$. The proton and carbon chemical shifts were referenced to internal TMS. One-dimensional $600 \mathrm{MHz}{ }^{1} \mathrm{H}-$ and $150 \mathrm{MHz}{ }^{13} \mathrm{C}$ NMR spectra, as well as two-dimensional COSY, HSQC and $\mathrm{HMBC}$, were used for determination of ${ }^{1} \mathrm{H}$ - and ${ }^{13} \mathrm{C}$ chemical shifts. Microwave reactions were performed in a multimode microwave reactor, CEM Discover, consisting of a continuously focused microwave power delivery 
system with operator-selectable power $0-300 \mathrm{~W}$, and microwave frequency source of $2.45 \mathrm{GHz}$.

\section{Synthesis of Alkyl Xylosides}

Monomeric D-xylose was obtained after microwave-induced Mo(VI)-catalyzed hydrolysis of beechwood xylan. The analysis of ${ }^{1} \mathrm{H}-\mathrm{NMR}$ spectra indicated that xylan was completely hydrolyzed and converted to the equilibrium mixture of pentoses (D-xylose and D-lyxose) as described previously [37]. A homologous series of amphiphilic long-chain alkyl D-xylosides [octyl D-xyloside $\left(\mathrm{C}_{8} \mathrm{X}\right)$, nonyl $\mathrm{D}$-xyloside $\left(\mathrm{C}_{9} \mathrm{X}\right)$, decyl $\mathrm{D}$-xyloside $\left(\mathrm{C}_{10} \mathrm{X}\right)$, and dodecyl D-xyloside $\left.\left(\mathrm{C}_{12} \mathrm{X}\right)\right]$ were prepared by microwave-assisted synthesis by direct coupling of unprotected D-xylose and the corresponding long-chain alcohol, in the presence of phosphomolybdic acid (PMoA) as promoter [18]. D-Xylose (6.66 mmol, 1 equiv.), $\mathrm{PMoA} / \mathrm{SiO}_{2}(0.06 \mathrm{mmol})$ and 5 equiv. of corresponding alcohol $\left(\mathrm{C}_{8}-\mathrm{C}_{12}\right)$ were mixed in Pyrex glass tubes and sealed with Teflon septa. The reaction mixture was exposed to microwave radiation $(150 \mathrm{~W})$ for 1-10 min. Work-up of the reaction mixture afforded the crude products which were purified by flash column chromatography on silica gel. The ratio of $\alpha / \beta$ anomers for individual alkyl D-xylosides present in the thermodynamic equilibrium mixture was determined by ${ }^{1} \mathrm{H}-$ NMR spectroscopy. For the long-chain alkyl D-xylosides, the $\alpha$-anomers were more prevalent; the anomeric ratio ranged from 57:43 $(\alpha: \beta)$ for $C_{8} X, 61: 39$ for $C_{9} X, 60: 40$ for $\mathrm{C}_{10} \mathrm{X}$ and $68: 32$ for $\mathrm{C}_{12} \mathrm{X}$. Magnitudes of protonproton spin-spin coupling constants across three bonds between $\mathrm{H}-1$ and $\mathrm{H}-2$ protons $\left({ }^{3} J_{\mathrm{H} 1-\mathrm{H} 2}\right)$ were $3.6-3.8 \mathrm{~Hz}$ for $\mathrm{C}_{8} \mathrm{X}-\mathrm{C}_{12} \mathrm{X}$ for $\alpha$-anomers. The ${ }^{3} J_{\mathrm{H} 1-\mathrm{H} 2}$ magnitudes agree with the ${ }^{4} \mathrm{C}_{1}$ form of the pyranose ring for these derivatives. The representative a $2 \mathrm{D}$ HSQC spectrum and a ${ }^{1} \mathrm{H}-\mathrm{NMR}$ conventional spectrum of 1 -nonyl- $\alpha / \beta-\mathrm{D}$ xylopyranoside, collected at the same experimental conditions, are shown in Fig. 1.

\section{Surface Active Properties}

\section{Surface Tension Measurements}

In order to measure the equilibrium surface tension of the surfactants' water solutions the du Noüy ring technique with an Easy Dyne K20 tensiometer with a platinum ring (Krüss, Germany) was used. The experiments were performed at $22 \pm 1{ }^{\circ} \mathrm{C}$. The surface tension data were fitted by adsorption equations. From a physicochemical point of view, the most appropriate was found to be the Szyszkowski equation [36]. Additionally, the solubility of the surfactants in deionized water was also evaluated [38].

\section{Emulsification Test}

The emulsification properties were evaluated based on measurements of optical density of the emulsion. The higher optical density is, the more dispersed the organic phase is [39]. $2.5 \mathrm{~mL}$ of the surfactants solutions in deionized water $(18.2 \mathrm{M} \Omega \mathrm{cm})$ at concentrations 10,50 , 100 and $250 \mathrm{mg} \mathrm{L}^{-1}$ were added to glass tubes. The sample was supplemented with $25 \mu \mathrm{L}$ of hexadecane. After mixing (using vortex shaker) for $1 \mathrm{~min}$, the sample was transferred into a spectrophotometric cuvette. The optical density at $600 \mathrm{~nm}\left(\mathrm{OD}_{600}\right)$ was measured for the first time immediately after shaking, and again after $15 \mathrm{~min}$.

\section{Foam Stability Test}

The foam stability test was conducted according to the method described by Belhaij and Mahdy [40]. The foam was generated during $1 \mathrm{~min}$ in a glass tube $(2 \mathrm{~cm}$ diameter) filled with $20 \mathrm{~mL}$ of surfactant solution, prepared as in the emulsification test. The height of the foam layer was measured at the moment the foam generation was stopped and 5 min after that moment.

\section{Microorganisms and Growth Conditions}

Further experiments were carried out using two bacterial strains from Pseudomonas genera: a reference strain Pseudomonas fluorescens ATCC 14700, and a strain Pseudomonas sp. KG1 (GenBank number KP096515), which was isolated from soil contaminated with crude oil, collected from sites in Southern Poland. The strains were kept on plates with Mueller-Hinton agar. The composition of culture mineral salts medium used throughout these studies was described by Kaczorek et al. [41]. A liquid culture was started by adding a loopful of cells from an agar plate into a $250 \mathrm{~mL}$ Schott Duran ${ }^{\circledR}$ laboratory glass bottles containing $50 \mathrm{~mL}$ of medium, and incubated overnight. Then, $5 \mathrm{~mL}$ of this liquid culture was used for the inoculation of the final culture to reach an optical density (measured at $600 \mathrm{~nm}$ ) ca. 1.0.

\section{Toxicity Measurements}

The toxicity of the tested surfactants on used bacterial strains was determined using the MTT cell proliferation assay, which is based on a transformation of tetrazolium dye MTT (3-(4,5-dimethylthiazol-2-yl)-2,5-diphenyltetrazolium bromide) to its formazan. This reaction is catalyzed by cellular reductases. The activity of these enzymes can be used for evaluation of the cell viability. The method was conducted according to Jafarirad et al. [42] after some modifications. Briefly, in $1.5 \mathrm{~mL}$ Eppendorf tubes the 


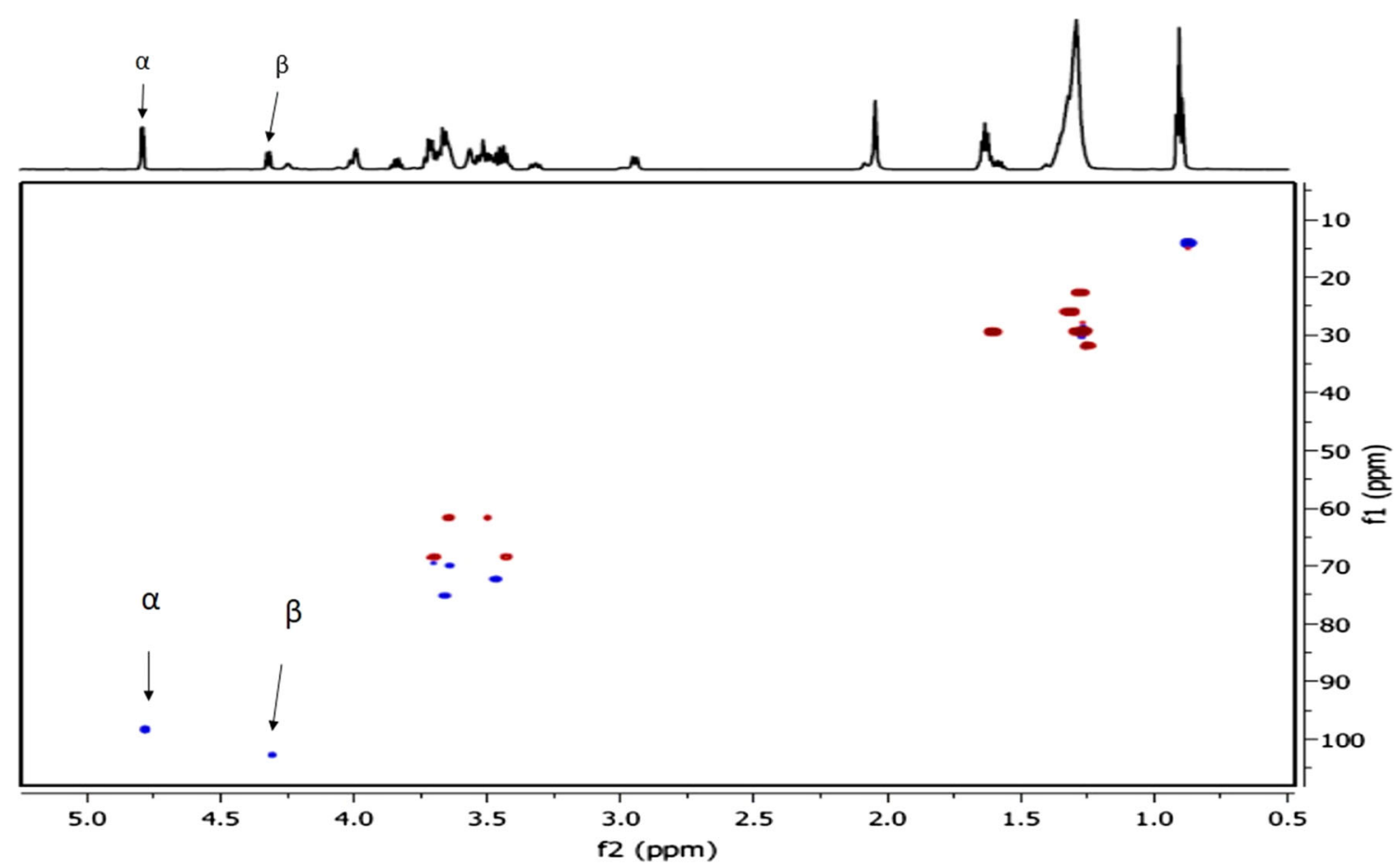

Fig. $12 \mathrm{D}$ HSQC spectrum and ${ }^{1} \mathrm{H}-\mathrm{NMR}$ conventional spectrum of 1 -nonyl- $\alpha / \beta-\mathrm{D}$ xylopyranoside, collected under the same experimental conditions

$0.1 \mathrm{~mL}$ of the MTT solution $\left(5 \mathrm{~g} \mathrm{~L}^{-1}\right)$ and $0.5 \mathrm{~mL}$ of bacteria cells suspension $\left(\mathrm{OD}_{600}=1.0\right)$ in the culture mineral medium were mixed. The samples were supplemented with the surfactants stock solutions. Finally, the different surfactant concentrations in the samples $(25,100$, 250, 500, $1000 \mathrm{mg} \mathrm{L}^{-1}$ ) were obtained. All samples were quenched up to $1.0 \mathrm{~mL}$ with the culture mineral medium. The control was the sample without the surfactant addition. Then the samples were incubated $\left(24 \mathrm{~h}, 30{ }^{\circ} \mathrm{C}\right)$ and shaken gently. Thereafter, the samples were centrifuged $(15,000 \mathrm{~g}$ for $5 \mathrm{~min})$, and after supernatant removal, the precipitate was dissolved in $1 \mathrm{~mL}$ of propan-1-ol. The samples were vortexed and centrifuged $(15,000 \mathrm{~g}, 5 \mathrm{~min})$ again. Then, the absorbance of the supernatant at $560 \mathrm{~nm}$ was measured (V-650 UV-Visible Spectrofotometer, Jasco, Japan). All values obtained were referred to the value obtained for the control.

\section{Cell Inner Membrane Permeability}

In order to evaluate the changes of the inner membrane permeability, the modified method described by Zhang et al. [43] was applied. Bacteria cells from the exponential growth phase were centrifuged at $8000 \mathrm{~g}$ for $5 \mathrm{~min}$ and cell suspension in a culture mineral medium was prepared. Then $0.1 \mathrm{~mL}$ of $o$-nitrophenyl- $\beta$-D-galactopyranoside (ONPG) in concentration $30 \mathrm{mmol} \mathrm{L}^{-1}$ and $0.5 \mathrm{~mL}$ of bacteria cells suspension $\left(\mathrm{OD}_{600}=1.0\right)$ in the culture mineral medium were added to 1.5-mL Eppendorf tubes. The samples were supplemented with the surfactant stock solutions to obtain the different surfactant concentrations in the samples $\left(10,25,100,250,500,1000 \mathrm{mg} \mathrm{L}^{-1}\right)$. All samples were quenched up to $1.0 \mathrm{~mL}$ with the culture mineral medium. The control was the sample without the surfactant addition. Next, the samples were incubated for $2 \mathrm{~h}$ at $28^{\circ} \mathrm{C}$. After this time suspension was centrifuged at $4000 \mathrm{~g}$ for $5 \mathrm{~min}$ and the supernatant was determined to be under $415 \mathrm{~nm}$.

\section{Cell Surface Hydrophobicity}

To determine the cell surface hydrophobicity the microbial adhesion to hydrocarbon method [44] in a modified version was chosen [45]. In prepared bacterial cultures the tested alkyl xylosides (at different concentrations 10, 25, 50 and $100 \mathrm{mg} \mathrm{L}^{-1}$ ) were used as carbon and energy sources. The control sample, without any surfactant, was the culture with glucose $\left(200 \mathrm{mg} \mathrm{L}^{-1}\right)$. The measurements were conducted after 7 days of incubation.

\section{Statistical Analysis}

All experiments were conducted in triplicate, and the mean values and statistical error were calculated. All the results obtained were statistically analyzed using SigmaStat 11.0 software. 


\section{Results and Discussion}

\section{Surface Active Properties}

The dependency between the surface tension and concentrations of the surfactants solutions was fitted to the Szyszkowski equation of the adsorption isotherm and the adsorption parameters were calculated (Table 1). These parameters allow a description of the behavior of the surfactant molecules in interphase. Considering the Gibbs free energy of adsorption, there can be a noticeable increase of it with a rising number of carbon atoms in alkyl chain. However, the values of the minimum surface occupied by a surfactant molecule are not correlated with alkyl chain length. The lowest minimum surface occupied by single surfactant molecule was obtained for $\mathrm{C}_{12} \mathrm{X}\left(2.69 \times 10^{-19}\right.$ $\mathrm{m}^{2}$ ), when the highest value of this parameter was noticed for $\mathrm{C}_{10} \mathrm{X}\left(4.68 \times 10^{-19} \mathrm{~m}^{2}\right)$. This phenomena could be interpreted that an alkyl chain length increase of two carbon atoms from decyl to dodecyl involves a significant change of molecular position in the interphase. The water solubility of the tested compounds was evaluated as 1.0, $0.42,0.20$ and $0.13 \mathrm{~g} \mathrm{~L}^{-1}$ for $\mathrm{C}_{8} \mathrm{X}, \mathrm{C}_{9} \mathrm{X}, \mathrm{C}_{10} \mathrm{X}$ and $\mathrm{C}_{12} \mathrm{X}$, respectively. Below these concentrations, the surfactants' solutions were colorless and transparent.

The critical micelle concentrations $(\mathrm{CMC})$ for $\mathrm{C}_{9} \mathrm{X}$ (3.010 mM), $\mathrm{C}_{10} \mathrm{X}(0.689 \mathrm{mM})$ and $\mathrm{C}_{12} \mathrm{X}(0.049 \mathrm{mM})$ were also evaluated. As mentioned above, the maximum solubility of $\mathrm{C}_{8} \mathrm{X}$ in water was observed at the concentration $1.0 \mathrm{~g} \mathrm{~L}^{-1}(3.8 \mathrm{mM})$. However, for surfactants from one homologous series there is a direct and simple correlation between the length of hydrocarbon chain and the logarithm of the CMC [19]. This dependency is also observed for the tested surfactants. Finally, the correlation equation was found and it allowed the calculation of the $\mathrm{CMC}$ for $\mathrm{C}_{8} \mathrm{X}(11.3 \mathrm{mM})$.

The surface active properties of alkyl xylosides were discussed by Bouxin et al. [46]. They found the CMC of octyl and decyl D-xylosides as $953 \mathrm{mg} \mathrm{L}^{-1}(3.63 \mathrm{mM})$ and $301 \mathrm{mg} \mathrm{L}^{-1}(1.03 \mathrm{mM})$, respectively. The presented results are three times lower than the values presented in these research, but the differences can be explained by different methods and conditions of the surface tension measurements. Additionally, the authors also used other synthesis method to obtain alkyl xylosides than in the presented study. Moreover, Marinkovic et al. [47], who used wheat straw as a substrate in the synthesis of decyl xylosides, observed the higher CMC values of obtained product than in the case of the surfactant produced from the pure D-xylose. The experimental data indicate the important influence of purity of the substrate on product properties.

The CMC of different alkyl derivatives of carbohydrates have been presented in several publications. López et al. [48] studied alkyl glucosides properties and presented the CMC values for octyl, nonyl, decyl and dodecyl glucoside: 18.0, 5.6, 1.8, $0.18 \mathrm{mM}$, respectively. Chaveriat et al. [49] observed the surface tension $28 \mathrm{mN} \mathrm{m}^{-1}$ at the CMC $(12 \mathrm{mM})$ for $6-O$-octyl-D-galactopyranose. Zhang et al. [50] found that the CMC value of $n$-dodecyl- $\beta$-D-maltoside equals to $0.18 \mathrm{mM}$.

Moreover, Laurent et al. [51] tested a different group of sugar-based surfactants, glucuronamides, and observed for octyl and dodecyl derivatives the $\mathrm{CMC}$ at $3.3 \mathrm{mM}$ $\left(\gamma_{\mathrm{CMC}}=24.4 \mathrm{mN} \mathrm{m}^{-1}\right) \quad$ and $0.7 \mathrm{mM} \quad\left(\gamma_{\mathrm{CMC}}=22.1-\right.$ $\mathrm{mN} \mathrm{m}^{-1}$ ) respectively. To illustrate, the CMC values for commercial surfactants are as followed: $0.08 \mathrm{mM}$ for Tween ${ }^{\circledR} 20$ [52], $20 \mathrm{mM}$ for Hecameg ${ }^{\circledR}$ [52], $8.35 \mathrm{mM}$ for sodium dodecyl sulfate [53], $15 \mathrm{mM}$ for dodecyltrimethylammonium bromide [50].

The tested compounds showed very strong surface active properties. The CMC values for alkyl xylosides were several times lower than those obtained for glucosides with analogical alkyl chains [48]. Simultaneously, the alkyl xylosides presented a significant possibility for a surface tension decrease. However, the surface tension values at CMC were comparable with those for glucuronamides [51]. The presented results indicate that toxicologically harmless and biodegradable alkyl xylosides, can be considered as an alternative for synthetic commercial surfactants.

\section{Emulsion and Foam Stability}

In order to investigate the surface active properties of these compounds two parameters were chosen, the stability of
Table 1 The evaluated adsorption parameters from the Szyszkowski equation for tested alkyl D-xylosides

\begin{tabular}{llll}
\hline Surfactant & $\Gamma_{\infty}\left[\mathrm{mol} \mathrm{m}^{-2}\right]$ & $A_{\min }\left[\mathrm{m}^{2}\right]$ & $-\Delta G_{\text {ads }}\left[\mathrm{kJ} \mathrm{mol}^{-1}\right]$ \\
\hline Octyl D-xyloside $\mathrm{C}_{8} \mathrm{X}$ & $4.27 \times 10^{6}$ & $3.89 \times 10^{-19}$ & 23.2 \\
Nonyl D-xyloside $\mathrm{C}_{9} \mathrm{X}$ & $4.61 \times 10^{6}$ & $3.61 \times 10^{-19}$ & 24.8 \\
Decyl D-xyloside $\mathrm{C}_{10} \mathrm{X}$ & $3.55 \times 10^{6}$ & $4.68 \times 10^{-19}$ & 30.6 \\
Dodecyl D-xyloside $\mathrm{C}_{12} \mathrm{X}$ & $6.18 \times 10^{6}$ & $2.69 \times 10^{-19}$ & 32.0 \\
\hline
\end{tabular}

$\Gamma_{\infty}$, surface excess at the saturated interface; $A_{\min }$, minimum surface area occupied by statistical molecule; $-\Delta G_{\text {ads }}$, Gibbs free energy of adsorption 
Table 2 Emulsification properties of the tested surfactants described by initial $\mathrm{OD}_{600}$ and $\mathrm{OD}_{600}$ decrease rate values

\begin{tabular}{|c|c|c|c|c|c|c|c|c|}
\hline & \multicolumn{8}{|c|}{ Surfactant concentration } \\
\hline & \multicolumn{2}{|l|}{$10 \mathrm{mg} \mathrm{L}^{-1}$} & \multicolumn{2}{|l|}{$50 \mathrm{mg} \mathrm{L}^{-1}$} & \multicolumn{2}{|l|}{$100 \mathrm{mg} \mathrm{L}^{-1}$} & \multicolumn{2}{|l|}{$250 \mathrm{mg} \mathrm{L}^{-1}$} \\
\hline & $\begin{array}{l}\text { Initial } \\
\text { OD }_{600}[-]\end{array}$ & $\begin{array}{l}\mathrm{OD}_{600} \text { decrease } \\
\text { rate }\left[\mathrm{min}^{-1}\right]\end{array}$ & $\begin{array}{l}\text { Initial } \\
\text { OD }_{600}[-]\end{array}$ & $\begin{array}{l}\mathrm{OD}_{600} \text { decrease } \\
\text { rate }\left[\mathrm{min}^{-1}\right]\end{array}$ & $\begin{array}{l}\text { Initial } \\
\text { OD }_{600}[-]\end{array}$ & $\begin{array}{l}\mathrm{OD}_{600} \text { decrease } \\
\text { rate }\left[\mathrm{min}^{-1}\right]\end{array}$ & $\begin{array}{l}\text { Initial } \\
\text { OD }_{600}[-]\end{array}$ & $\begin{array}{l}\mathrm{OD}_{600} \text { decrease } \\
\text { rate }\left[\mathrm{min}^{-1}\right]\end{array}$ \\
\hline $\mathrm{C}_{8} \mathrm{X}$ & $1.02 \pm 0.05$ & $0.025 \pm 0.001$ & $2.08 \pm 0.10$ & $0.021 \pm 0.002$ & $2.15 \pm 0.11$ & $0.016 \pm 0.002$ & $2.96 \pm 0.15$ & $0.008 \pm 0.001$ \\
\hline $\mathrm{C}_{9} \mathrm{X}$ & $1.68 \pm 0.08$ & $0.032 \pm 0.002$ & $2.65 \pm 0.13$ & $0.015 \pm 0.001$ & $2.58 \pm 0.13$ & $0.013 \pm 0.002$ & $2.68 \pm 0.13$ & $0.013 \pm 0.002$ \\
\hline $\mathrm{C}_{10} \mathrm{X}$ & $2.23 \pm 0.11$ & $0.032 \pm 0.002$ & $2.84 \pm 0.14$ & $0.026 \pm 0.005$ & $2.86 \pm 0.14$ & $0.023 \pm 0.003$ & $2.88 \pm 0.14$ & $0.017 \pm 0.002$ \\
\hline $\mathrm{C}_{12} \mathrm{X}$ & $1.98 \pm 0.10$ & $0.033 \pm 0.002$ & $2.66 \pm 0.13$ & $0.016 \pm 0.002$ & $2.89 \pm 0.14$ & $0.013 \pm 0.001$ & $2.77 \pm 0.14$ & $0.018 \pm 0.002$ \\
\hline
\end{tabular}

$\mathrm{C}_{8} \mathrm{X}$, octyl D-xyloside; $\mathrm{C}_{9} \mathrm{X}$, nonyl D-xyloside; $\mathrm{C}_{10} \mathrm{X}$, decyl D-xyloside; $\mathrm{C}_{12} \mathrm{X}$, dodecyl D-xyloside

Table 3 The foam measurements for tested surfactants

\begin{tabular}{|c|c|c|c|c|c|c|}
\hline & \multicolumn{6}{|c|}{ Surfactant concentration } \\
\hline & \multicolumn{2}{|l|}{$50 \mathrm{mg} \mathrm{L}^{-1}$} & \multicolumn{2}{|l|}{$100 \mathrm{mg} \mathrm{L}^{-1}$} & \multicolumn{2}{|l|}{$250 \mathrm{mg} \mathrm{L}^{-1}$} \\
\hline & $\mathrm{H}_{0}[\mathrm{~mm}]$ & $\mathrm{H}_{5}[\mathrm{~mm}]$ & $\mathrm{H}_{0}[\mathrm{~mm}]$ & $\mathrm{H}_{5}[\mathrm{~mm}]$ & $\mathrm{H}_{0}[\mathrm{~mm}]$ & $\mathrm{H}_{5}[\mathrm{~mm}]$ \\
\hline $\mathrm{C}_{8} \mathrm{X}$ & $9.1 \pm 0.5$ & $1.2 \pm 0.2$ & $9.8 \pm 0.3$ & $5.1 \pm 0.2$ & $10.2 \pm 0.3$ & $9.2 \pm 0.3$ \\
\hline $\mathrm{C}_{9} \mathrm{X}$ & $14.8 \pm 0.8$ & $6.3 \pm 0.3$ & $16.7 \pm 0.3$ & $11.8 \pm 0.3$ & $19.9 \pm 0.4$ & $14.1 \pm 0.3$ \\
\hline $\mathrm{C}_{10} \mathrm{X}$ & $43.2 \pm 1.2$ & $35.1 \pm 0.5$ & $60.2 \pm 0.4$ & $53.1 \pm 0.3$ & $39.8 \pm 0.4$ & $35.2 \pm 0.4$ \\
\hline $\mathrm{C}_{12} \mathrm{X}$ & $15.9 \pm 0.8$ & $1.1 \pm 0.2$ & $40.1 \pm 0.4$ & $2.2 \pm 0.4$ & $60.1 \pm 0.5$ & $45.1 \pm 0.5$ \\
\hline
\end{tabular}

$\mathrm{H}_{0}$ and $\mathrm{H}_{5}$ represent the height of the foam layer in a cylinder, when the foam generation was stopped and 5 min after then

$\mathrm{C}_{8} \mathrm{X}$, octyl D-xyloside; $\mathrm{C}_{9} \mathrm{X}$, nonyl D-xyloside; $\mathrm{C}_{10} \mathrm{X}$, decyl D-xyloside; $\mathrm{C}_{12} \mathrm{X}$, dodecyl D-xyloside the emulsion and the foam. The method for measurements of emulsifying capacity of the surfactant water solutions is based on the assumption that the higher $\mathrm{OD}_{600}$ is, the more dispersed the emulsion is. Moreover, the lower the absorbance decrease rate is, the more stable the emulsion is. The obtained results are presented in Table 2.

The emulsification properties increased with the increased alkyl chain length, obtained maximum for $\mathrm{C}_{10} \mathrm{X}$, and dropped slightly for $\mathrm{C}_{12} \mathrm{X}$. However, the difference in dispersion ratio is more significant at lower concentration. What is more, emulsion decrease, measured by $\mathrm{OD}_{600}$ decrease rate, declined with the rising surfactant concentration for all tested compounds.

Emulsifiability of alkyl $\beta$-D-galactopyranosides, from $\mathrm{C}_{6}$ to $\mathrm{C}_{9}$, was investigated by Chen et al. [54]. They noticed the increase of height of emulsion level with an increasing number of carbons. Alkyl glucopyranosides were also studied by Niraula et al. [55] with similar conclusions.

The results of foam formation and its stability for tested alkyl xylosides are summarized in Table 3. For the concentration $10 \mathrm{mg} \mathrm{L}^{-1}$ the measurements were also conducted, however, in the case of each surfactant, no stable foam was observed. The increase of foam layer height with the increasing alkyl xylosides concentration was observed for all compounds except for decyl xyloside.
For this surfactant the highest foam was generated at the concentration $50 \mathrm{mg} \mathrm{L}^{-1}$ (initial height $60.2 \mathrm{~mm}$ ). Such phenomena may be correlated with a relative high minimum surface occupied by a surfactant molecule, $4.68 \times 10^{-19} \mathrm{~m}^{2}$ and a low surface excess at the saturated interface, $3.55 \times 10^{6} \mathrm{~mol} \mathrm{~m}^{-2}$ (Table 1). These parameters indicate that, among the tested surfactants, $\mathrm{C}_{10} \mathrm{X}$ requires the lowest number of molecules necessary to the saturate the interfacial surface. Moreover, the longer alkyl chain yielded the more stable and more dispersed emulsion. The only significant exception is low foam stability for $\mathrm{C}_{12} \mathrm{X}$. This may be caused by the more hydrophobic properties of this surfactant, which influenced foam bubble formation.

The obtained results clearly illustrate the influence of the alkyl chain length on the surfactant foaming properties. Such conclusions were found in several publications [56-58]. Badache et al. [21] noticed that a longer alkyl chain of the surfactant is connected with the increasing foamability. Moreover, Koeltzow and Urefer [59] compared the foam amount generated in solutions of alkyl maltopyranosides and maltotriopyranosides with alkyl chain containing from 8 to 18 carbon atoms. They found out that the highest foam level at $1 \mathrm{~g} \mathrm{~L}^{-1}$ was found for a tridecyl chain. Chen et al. [54] observed also a maximum 
Fig. 2 Toxicity of tested surfactants represented by relative cell metabolic activity measured using the MTT assay, the values for: a Pseudomonas fluorescens ATCC 14700, b Pseudomonas sp. KG1
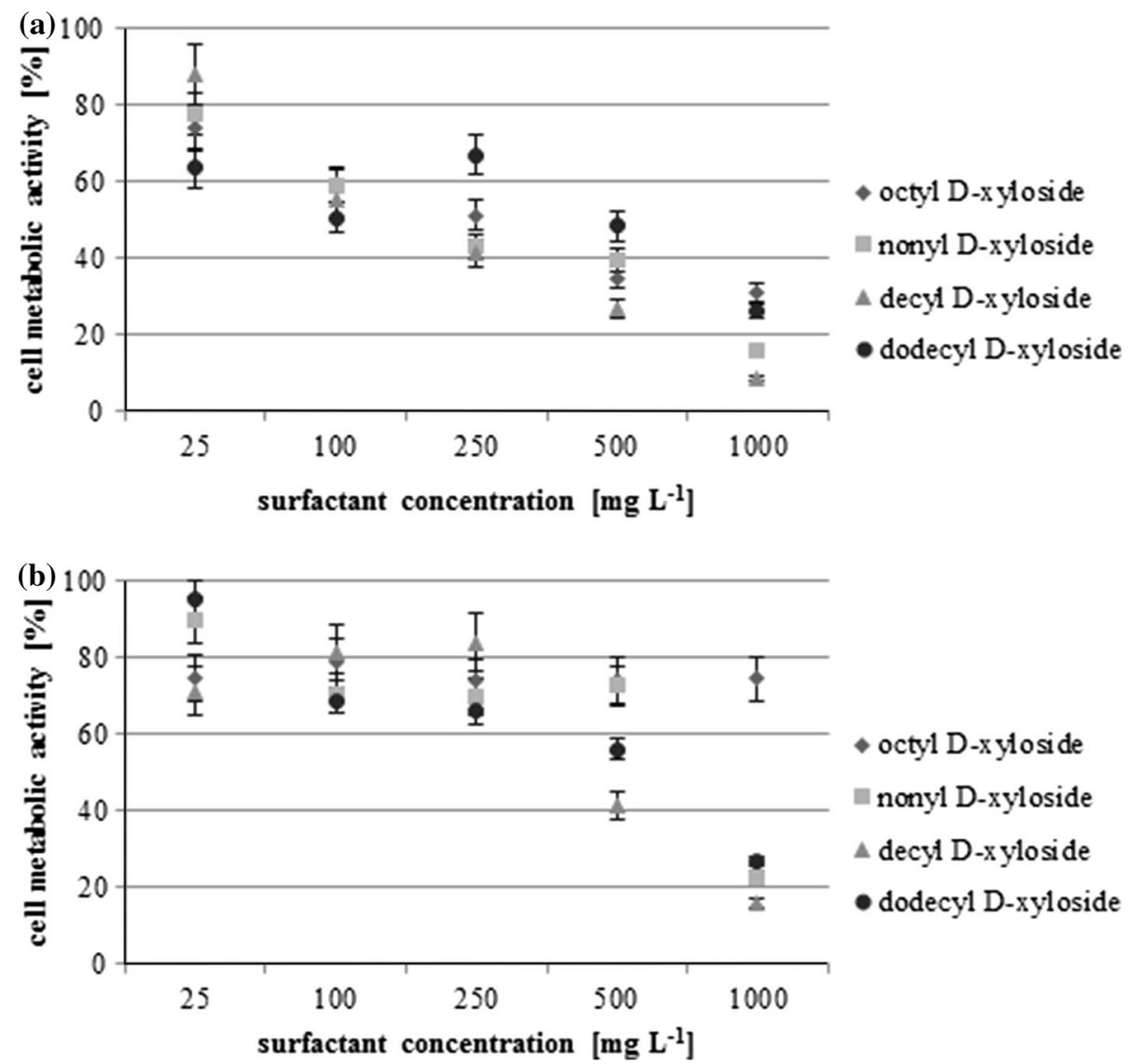

in the function between alkyl chain length and the foaming ability of alkyl $\beta$-D-galactopyranosides.

\section{Toxicity of Surfactants}

The toxicity of the tested compounds was determined using the MTT assay, indicating the cell metabolic activity. All results were compared with the reference sample without any surfactant, value of which was set as $100 \%$.

The $P$. fluorescens strain was more sensitive than the other strain to the presence of these surfactants (Fig. 2a). The $50 \%$ decrease in the cell metabolic activity was observed for $\mathrm{C}_{8} \mathrm{X}$ and $\mathrm{C}_{10} \mathrm{X}$ at a concentration of $250 \mathrm{mg} \mathrm{L}^{-1}$. At the same concentration the metabolic activity of $\mathrm{C}_{9} \mathrm{X}$ and $\mathrm{C}_{12} \mathrm{X}$ was 55 and $65 \%$ respectively. At the highest tested concentration, $1000 \mathrm{mg} \mathrm{L}^{-1}$, the metabolic activity did not exceed $35 \%$ for $\mathrm{C}_{8} \mathrm{X}$ and $10 \%$ for $\mathrm{C}_{10} \mathrm{X}$.

In the case of Pseudomonas sp. KG1 (Fig. 2b), the cell metabolic activity in the presence of $\mathrm{C}_{8} \mathrm{X}$ did not fall below $70 \%$ even at the highest concentration. This level was not exceeded for $\mathrm{C}_{9} \mathrm{X}$ at $500 \mathrm{mg} \mathrm{L}^{-1}$, and at $250 \mathrm{mg} \mathrm{L}^{-1}$ for two other compounds. The metabolic activity at $1000 \mathrm{mg} \mathrm{L}^{-1}$ for $\mathrm{C}_{9} \mathrm{X}, \mathrm{C}_{10} \mathrm{X}$ and $\mathrm{C}_{12} \mathrm{X}$ was lower than $30 \%$.
In the literature there are practically no studies about toxicity of alkyl xylosides. Xu et al. [60] studied cytotoxicity of alkyl $\beta$-D-xylopyranosides in mammalian cells, but no impact on bacteria cells was examined. However, the obtained results correspond well with those obtained by Jurado et al. [61] for alkyl polyglucosides. Their results indicated that the toxicity increased as the CMC value decreased, which occurs, when the alkyl chain is longer. Such correlation was also noticed in the case of the toxicity of alkyl polyglucosides against other microorganisms, e.g. Vibrio fischeri or Daphnia magna [62]. Sahariah et al. [63] studied the antibacterial activity of a different group of compounds, $\mathrm{N}, \mathrm{N}$-dialkyl chitosan derivatives, against several Gram-positive strains. They also found out, that the toxicity is correlated with the length of the alkyl chain. However, the order was dependent on the bacterial strain.

\section{Cell Surface Modifications}

In order to investigate the impact of the surface active compounds on bacteria cells the cell surface hydrophobicity as well as cell membrane permeability can be considered as sensitive and valuable parameters. The changes of a cell inner membrane in the presence of the surfactants are presented in Fig. 3. What is important, the both strains 

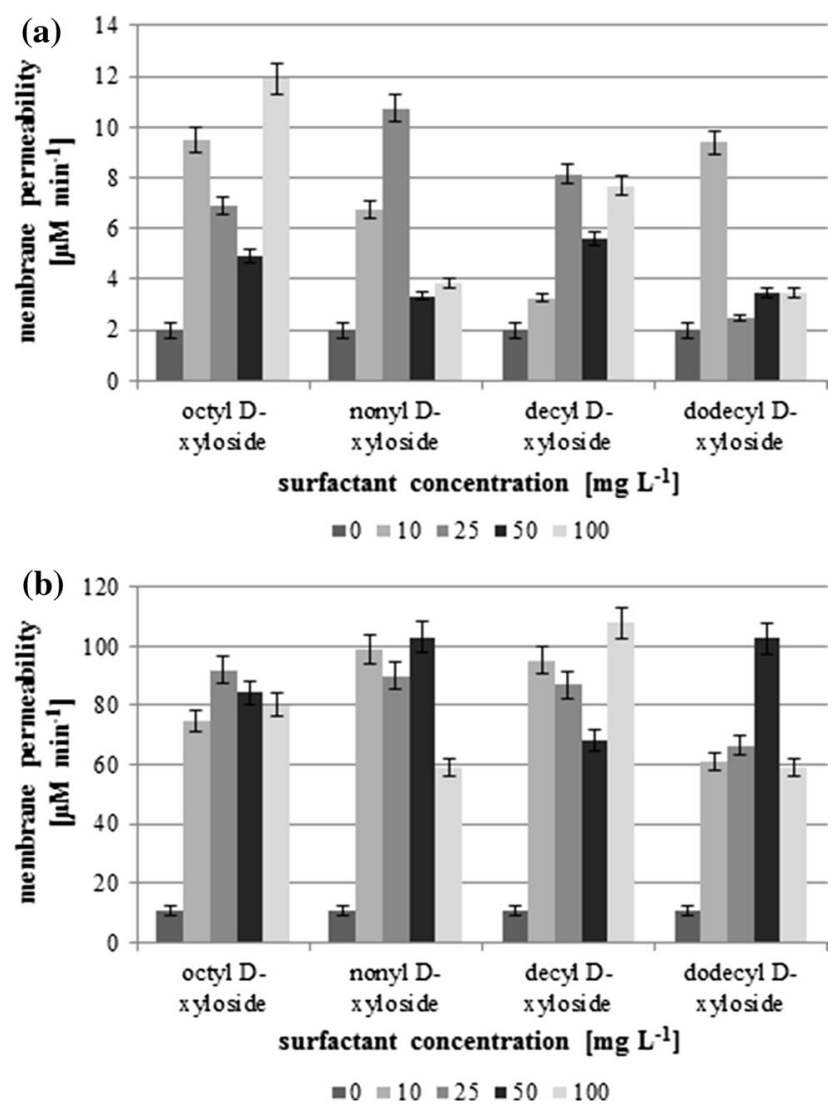

Fig. 3 Inner cell membrane permeability changes in the presence of tested alkyl xylosides, a Pseudomonas fluorescens ATCC 14700, b Pseudomonas sp. KG1

from the same genera, possessed very different initial values of the membrane permeability, 2 and $12 \mu \mathrm{M} \mathrm{min}{ }^{-1}$, for Pseudomonas fluorescens and Pseudomonas sp. KG1, respectively. Although, the values differ about ten times between the used strains, in both cases the addition of the tested compounds results in an increase in membrane permeability. However, no correlation between the surfactant concentration and the membrane permeability was found. For $P$. fluorescens, the highest value was observed at $100 \mathrm{mg} \mathrm{L}^{-1}\left(\mathrm{C}_{8} \mathrm{X}\right), 25 \mathrm{mg} \mathrm{L}^{-1}\left(\mathrm{C}_{9} \mathrm{X}\right.$ and $\left.\mathrm{C}_{10} \mathrm{X}\right)$ or $10 \mathrm{mg} \mathrm{L}^{-1}\left(\mathrm{C}_{12} \mathrm{X}\right)$. In the case of the second strain, Pseudomonas sp. KG1, the rise of cell permeability is more significant, and even at concentration $10 \mathrm{mg} \mathrm{L}^{-1}$ the permeability increases over six $\left(\mathrm{C}_{12} \mathrm{X}\right)$, seven $\left(\mathrm{C}_{8} \mathrm{X}\right)$ or nine $\left(\mathrm{C}_{9} \mathrm{X}\right.$ and $\left.\mathrm{C}_{12} \mathrm{X}\right)$ times.

Analyzing the changes of the cell surface hydrophobicity (CSH) the different strains' response on the presence of the surfactants can be observed. The cells of the reference strain, $P$. fluorescens, were hydrophilic $(\mathrm{CSH}<35 \%)$ and did not change with rising surfactant concentration (Fig. 4a). More significant cell surface properties modifications were observed in several cases only. The increase up to 36 and $28 \%$ was noticed for $\mathrm{C}_{10} \mathrm{X}\left(100 \mathrm{mg} \mathrm{L}^{-1}\right)$ and
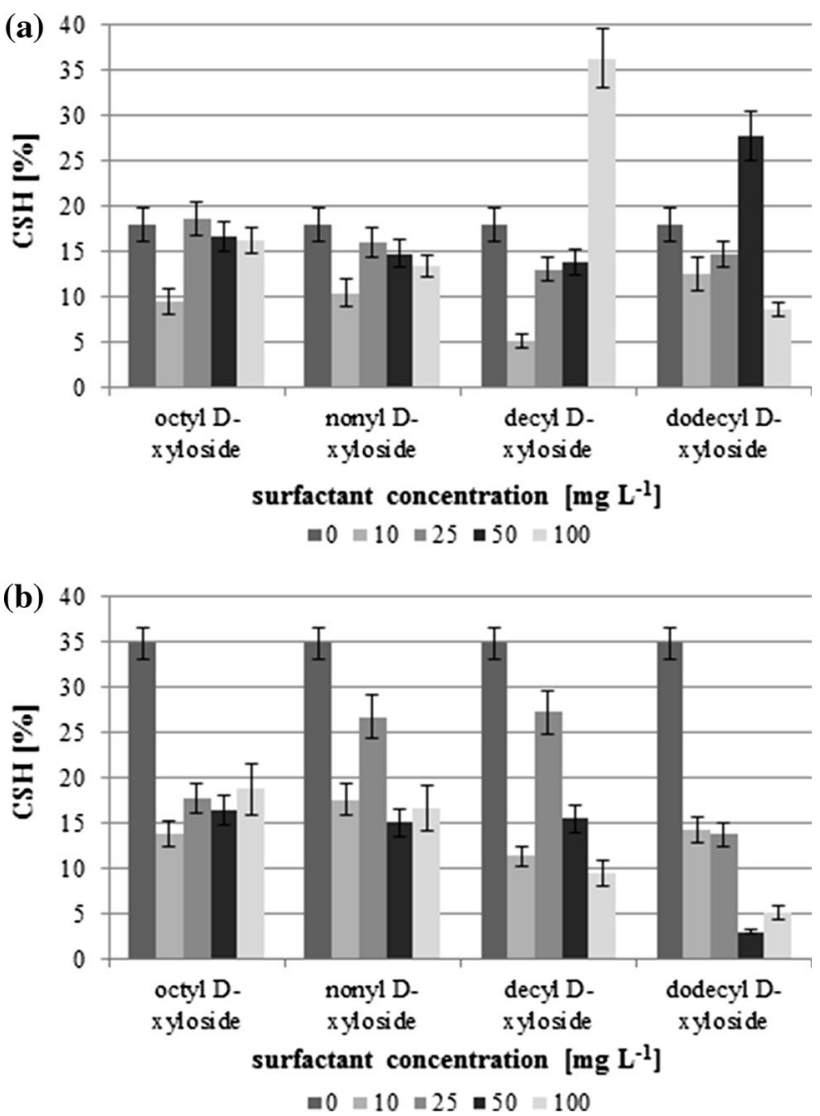

Fig. 4 Cell surface hydrophobicity (CSH) a Pseudomonas fluorescens ATCC 14700, b Pseudomonas sp. KG1

$\mathrm{C}_{12} \mathrm{X}\left(50 \mathrm{mg} \mathrm{L}^{-1}\right)$, respectively. The noticeable drop in $\mathrm{CSH}$ was observed at $10 \mathrm{mg} \mathrm{L}^{-1}$, especially for $\mathrm{C}_{10} \mathrm{X}$. The response of the Pseudomonas sp. KG1 strain cells was different (Fig. 4b). In all cases the significant decrease of $\mathrm{CSH}$ was noticed. The initial CSH was at the level 35\% and the values dropped even below $5 \%$ for $\mathrm{C}_{12} \mathrm{X}$ at concentrations higher than $50 \mathrm{mg} \mathrm{L}^{-1}$. Comparing both analyzed parameters, it can be noticed, that, in general, an increase of the cell surface hydrophobicity is accompanied by a decrease of the cell membrane permeability.

The compounds with surface activity are considered as an important modifier of a cell membrane structure and its permeability [64]. Tobe et al. [65] observed that methyl ester ethoxylates increase the permeability of the Escherichia coli cell membrane. On the other hand, Fuchedzhieva et al. [66] noticed that benzene sulfonates (LAS) with linear alkyl chain did not affect the microbial cell permeability of Pseudomonas sp. PS-17. It could suggest that the hydrophilic carbohydrate headgroup in alkyl xylosides can play an important role in membrane permeability changes.

The several studies conducted by different researchers suggest that surfactants can be one of the agents influencing cell surface hydrophobicity [33, 41, 67]. The carbohydrate-based surfactants with longer alkyl chains, like 
alkyl polyglucosides, can affect bacterial surface properties as well. However, the simple dependence between the alkyl chain length or surfactant concentration was not observed [45].

\section{Conclusions}

In summary, we have observed that the tested long-chain alkyl xylosides showed significant surface active properties. They showed considerable ability for surface tension reduction, even at relatively low concentrations. The direct correlation between the number of carbon atoms in the alkyl chain and logarithm of the critical micelle concentration of the surfactants was observed. The analyzed compounds showed also good emulsifying and foaming properties. All tested compounds did not show any toxic influence on two Pseudomonas strains at concentrations below $25 \mathrm{mg} \mathrm{L}^{-1}$. The surfactants influence both the cell inner membrane permeability and cell surface hydrophobicity. However, the character of the modification depends strongly on the bacteria strain, alkyl chain length, as well as on the surfactant concentration. The studied long-chain alkyl xylosides have potential as environmentally friendly surfactants due to their interesting physico-chemical and eco-toxicological profiles.

Acknowledgements The authors acknowledge the financial support from the Slovak Grant Agency VEGA Grant No. 2/0100/14, SP Grant 2003SP200280203 and the research Grant No. 3/32/DSPB/0600 from Poznan University of Technology.

Open Access This article is distributed under the terms of the Creative Commons Attribution 4.0 International License (http://crea tivecommons.org/licenses/by/4.0/), which permits unrestricted use, distribution, and reproduction in any medium, provided you give appropriate credit to the original author(s) and the source, provide a link to the Creative Commons license, and indicate if changes were made.

\section{References}

1. Matsumura S, Imai K, Yoshikawa S, Kowada K, Uchibori T. Surface activities, biodegradability and antimicrobial properties of n-alkyl glucosides, mannosides and galactosides. J Oil Fat Ind. 1990;67:996-1001.

2. Rodrigues L, Banat IM, Teixeira J, Oliveira R. Biosurfactants: potential applications in medicine. $\mathrm{J}$ Antimicrob Chemother. 2006;57:609-18.

3. Sharma DK, Lambu MR, Sidiq T, Khajuria A, Tripathi AK, Yousuf SK, Mukherjee D. Ammonium chloride mediated synthesis of alkyl glycosides and evaluation of their immunomodulatory activity. RSC Adv. 2013;3:11450-5.

4. Ruiz CC. Sugar-based surfactants, fundamentals and applications. 1st ed. Boca Raton: CRC Press, Taylor \& Francis group; 2009.
5. von Rybinski W, Hill K. Alkyl polyglucosides-Properties and applications of a new class of surfactants. Angew Chem Int Ed. 1998;37:1328-45.

6. Villandier N, Corma A. One pot catalytic conversion of cellulose into biodegradable surfactants. Chem Commun. 2010;46:4408-10.

7. Söderlind E, Wollbratt M, von Corswant C. The usefulness of sugar surfactants as solubilizing agents in parenteral formulations. Int J Pharm. 2003;252:61-71.

8. Balzer D, Lüders H. Nonionic surfactants, alkyl polyglucosides. 1st ed. New York: Marcel Dekker Inc.; 2000.

9. Kaczorek E, Smułek W, Zgoła-Grześkowiak A, Bielicka-Daszkiewicz K, Olszanowski A. Effect of Glucopon 215 on cell surface properties of Pseudomonas stutzeri and diesel oil biodegradation. Int Biodeter Biodegr. 2015;104:129-35.

10. Liu F, Wang C, Liu X, Liang X, Wang Q. Effects of alkyl polyglucoside (APG) on phytoremediation of PAH-contaminated soil by an aquatic plant in the Yangtze estuarine wetland. Water Air Soil Pollut. 2013;224:1633.

11. Zhang F, Gu W, Xu P, Tang S, Xie K, Huang X, Huang Q. Effects of alkyl polyglucoside (APG) on composting of agricultural wastes. Waste Manage. 2011;31:1333-8.

12. Jiang Z, Zhu Y, Li L, Yu X, Kusakabe I, Kitaoka M, Hayashi K. Transglycosylation reaction of xylanase B from the hyperthermophilic Thermotoga maritima with the ability of synthesis of tertiary alkyl $\beta$-D-xylobiosides and xylosides. J Biotechnol. 2004; 114:125-34.

13. Ochs M, Muzard M, Plantier-Royon R, Estrine B, Rémond C. Enzymatic synthesis of alkyl $\beta$-D-xylosides and oligoxylosides from xylans and from hydrothermally pretreated wheat bran. Green Chem. 2011;13:2380-8.

14. Bouxin F, Marinkovic S, Le Bras J, Estrine B. Direct conversion of xylan into alkyl pentosides. Carbohyd Res. 2010;345:2469-73.

15. Sekine M, Kimura T, Katayama Y, Takahashi D, Toshima K. The direct and one-pot transformation of xylan into the biodegradable surfactants, alkyl xylosides, is aided by an ionic liquid. RSC Adv. 2013;3:19756-9.

16. Ludot C, Estrine B, Le Bras J, Hoffmann N, Marinkovic S, Muzart J. Sulfoxides and sulfones as solvents for the manufacture of alkyl polyglycosides without added catalyst. Green Chem. 2013;15:3027-30.

17. Hricovíniová Z, Hricovíni M. An efficient synthesis of novel Lrhamnose based non-ionic surfactants under controlled microwave irradiation. Tetrahedron Asymmetry. 2014;25:1008-14.

18. Hricovíniová Z. Surfactants of biological origin: the role of $\mathrm{Mo}(\mathrm{VI})$ and microwaves in the synthesis of xylan-based nonionic surfactants. Carbohydr Polym. 2016;144:297-304.

19. Staszak K, Wieczorek D, Zieliński R. Synthesis and interfacial activity of novel sulfobetaines in aqueous solutions. Tens Surf Deterg. 2013;50(1):45-51.

20. Rosen MJ. Surfactants and interfacial phenomena. 3rd ed. Hoboken: John Wiley \& Sons Inc.; 2004.

21. Badache L, Lehanine Z, Abderrahmane WN. Synthesis and surface properties study of a series of cationic surfactants with different hydrophobic chain lengths. J Surfactants Deterg. 2012;15(6):715-20.

22. Ni B-Q, Hu J, Liu X-F, Chen H, Fang Y. Effect of long-chain length on the surface activities of zwitterionic imidazolium-based surfactants: 1-Carboxymethyl-3-alkylimidazolium inner salts. J Surfactants Deterg. 2012;15(6):729-34.

23. Wu X-L, Chu Y-P, Huang Y-P, Xu Z-C, Zhang L, Zhang L, Zhao $S$. Effect of alkyl chain length on the interfacial dilational properties of hydroxy-substituted alkyl benzenesulfonates. J Dispers Sci Technol. 2016;37(12):1738-44. 
24. Rengstl D, Diat O, Klein R, Kunz W. Influence of chain length and double bond on the aqueous behavior of choline carboxylate soaps. Langmuir. 2013;29(8):2506-19.

25. Ghosh S, Ray A. Alkyl chain length asymmetry effects of mixed n-acyl sarcosinate and $N$-cetylpyridinium chloride surfactants: spontaneous formation of stable nanovesicles as excipient. Coll Surf A. 2014;461(1):248-57.

26. Koh A, Linhardt RJ, Gross R. Effect of sophorolipid n-alkyl ester chain length on its interfacial properties at the almond oil-water interface. Langmuir. 2016;32(22):5562-72.

27. Kegel LL, Szabó LZ, Polt R, Pemberton JE. Alkyl melibioside and alkyl cellobioside surfactants: effect of sugar headgroup and alkyl chain length on performance. Green Chem. 2016;18(16):4446-60.

28. Oliver RC, Lipfert J, Fox DA, Lo RH, Doniach S, Columbus L. Dependence of micelle size and shape on detergent alkyl chain length and head group. PLoS ONE. 2013;8(5):62488.

29. Matsson MK, Kronberg B, Claesson PM. Adsorption of alkyl polyglucosides on the solid/water interface: equilibrium effects of alkyl chain length and head group polymerization. Langmuir. 2004;20(10):4051-8.

30. Jardak K, Drogui P, Daghrir R. Surfactants in aquatic and terrestrial environment: occurrence, behaviour, and treatment processes. Environ Sci Pollut Res. 2016;23(4):3195-216.

31. Könnecker G, Regelmann J, Belanger S, Gamon K, Sedlak R. Environmental properties and aquatic hazard assessment of anionic surfactants: physico-chemical, environmental fate and ecotoxicity properties. Ecotoxicol Environ Saf. 2011;74(6):1445-60.

32. Shen H-B, Yong X-Y, Chen Y-L, Liao Z-H, Si R-W, Zhou J, Wang S-Y, Yong Y-C, OuYang P-K, Zheng T. Enhanced bioelectricity generation by improving pyocyanin production and membrane permeability through sophorolipid addition in Pseudomonas aeruginosa-inoculated microbial fuel cells. Bioresour Technol. 2014;167:490-4.

33. Mohanty S, Mukherji S. Alteration in cell surface properties of Burkholderia spp. during surfactant-aided biodegradation of petroleum hydrocarbons. Appl Microbiol Biotechnol. 2012;94(1):193-204.

34. Tran VB, Sung YS, Copley K, Radke CJ. Effects of aqueous polymeric surfactants on silicone-hydrogel soft- contact-lens wettability and bacterial adhesion of Pseudomonas aeruginosa. Cont Lens Anterior Eye. 2012;35(4):155-62.

35. Belanger SE, Sanderson H, Fisk PR, Schäfers C, Mudge SM, Willing A, Kasai Y, Nielsen AM, Dyer SD, Toy R. Assessment of the environmental risk of long-chain aliphatic alcohols. Ecotoxicol Environ Saf. 2009;72(4):1006-15.

36. Smułek W, Zdarta A, Łuczak M, Krawczyk P, Jesionowski T, Kaczorek E. Sapindus saponins' impact on hydrocarbon biodegradation by bacteria strains after short- and long-term contact with pollutant. Coll Surf B. 2016;142:207-13.

37. Hricovíniová $Z$. Xylans are a valuable alternative resource: production of d-xylose, D-lyxose and furfural under microwave irradiation. Carbohydr Polym. 2013;98:1416-21.

38. Pollard JM, Shi AJ, Göklen KE. Solubility and partitioning behaviour of surfactants and additives used in bioprocesses. J Chem Eng Data. 2006;51(1):230-6.

39. Sneha KS, Padmapriya B, Rajeswari T. Isolation and screening of biosurfactants produced by Pseudomonas aeruginosa from oil spilled soils. Int J Pharm Biol Arch. 2012;3(2):321-5.

40. Belhaij A, Mahdy O. Foamability and foam stability of several surfactants solutions: the role of screening and flooding. J Pet Environ Biotechnol. 2015;6:227.

41. Kaczorek E, Urbanowicz M, Olszanowski A. The influence of surfactants on cell surface properties of Aeromonas hydrophila during diesel oil biodegradation. Coll Surf B. 2010;81:363-8.
42. Jafarirad S, Mehrabi M, Divband B, Kosari-Nasab M. Biofabrication of zinc oxide nanoparticles using fruit extract of Rosa canina and their toxic potential against bacteria: a mechanistic approach. Mat Sci Eng C. 2016;59:296-302.

43. Zhang D, Zhu L, Li F. Influences and mechanisms of surfactants on pyrene biodegradation based on interactions of surfactant with a Klebsiella oxytoca strain. Bioresour Technol. 2013;142:454-61.

44. Rosenberg M. Bacterial adherence to hydrocarbon: a useful technique for studying cell surface hydrophobicity. FEMS Microbiol Lett. 1984;22:289-95.

45. Smułek W, Zdarta A, Milewska M, Kaczorek E. Alkyl polyglucosides as cell surface modification factors: influence of the alkyl chain length. Toxicol Environ Chem. 2016;98(1):13-25.

46. Bouxin F, Marinkovic S, Le Bras J, Estrine B. Direct conversion of xylan into alkyl pentosides. Carbohydr Polym. 2010;345:2469-73.

47. Marinkovic S, Le Bras J, Nardello-Rataj V, Agach M, Estrine B. Acidic pretreatment of wheat straw in decanol for the production of surfactant, lignin and glucose. Int J Mol Sci. 2012;13:348-57.

48. López O, Cócera M, Parra JL, de la Maza A. Influence of the alkyl chain length of alkyl glucosides on their ability to solubilize phosphatidylcholine liposomes. Coll Surf A. 2001;193(1-3):221-9.

49. Chaveriat L, Gosselin I, Machut C, Martin P. Synthesis, surface tension properties and antibacterial activities of amphiphilic Dgalactopyranose derivatives. Eur J Med Chem. 2013;62:177-86.

50. Zhang R, Zhang L, Somasundaran P. Study of mixtures of n-dodecyl- $\beta$-D-maltoside with anionic, cationic, and nonionic surfactant in aqueous solutions using surface tension and fluorescence techniques. J Coll Interface Sci. 2004;278(2):453-60.

51. Laurent $\mathrm{P}$, Razafindralambo H, Wathelet B, Blecker C, Wathelet J-P, Paquot M. Synthesis and surface-active properties of uronic amide derivatives, surfactants from renewable organic raw materials. J Surfactants Deterg. 2011;14:51-61.

52. Lu B, Vayssade M, Miao Y, Chagnault V, Grand E, Wadouachi A, Postel D, Drelich A, Egles C, Pezron I. Physico-chemical properties and cytotoxic effects of sugar-based surfactants: impact of structural variations. Coll Surf B. 2016;145:79-86.

53. Saien J, Akbari S. Interfacial tension of toluene + water + sodium dodecyl sulfate from 20 to $50 \& \# \mathrm{xB} 0 ; \mathrm{C}$ and $\mathrm{pH}$ between 4 and 9. J Chem Eng Data. 2006;51:1832-5.

54. Chen G, Li Z, Chen L, Ji S, Shen W. Synthesis and properties of alkyl $\quad \beta$-D-galactopyranoside. J Surfactants Deterg. 2016;19:1095-105.

55. Niraula B, King TC, Chun TK, Misran M. Rheology properties of glucopyranoside stabilized oil-water emulsions: effect of alkyl chain length and bulk concentration of the surfactant. Coll Surf A. 2004;251(1-3):117-32.

56. Zhu H-L, Hu Z-Y, Wang M-L, Cao D-L. Synthesis and properties of alkyl dibenzyl ether quaternary ammonium gemini surfactant. Tenside Surfact Det. 2015;52(2):163-9.

57. van Kempen SEHJ, Schols HA, van der Linden E, Sagis LMC. Effect of variations in the fatty acid chain of oligofructose fatty acid esters on their foaming functionality. Food Biophys. 2014;9(2):114-24.

58. Song X-W, Zhang L, Wang X-C, Zhang L, Zhao S, Yu J-Y. Study on foaming properties of polyoxyethylene alkyl ether carboxylic salts with different structures. J Dispers Sci Technol. 2011;32(2):247-53.

59. Koeltzow DE, Urefer AD. Preparation and properties of pure alkyl glucosides, maltosides and maltotriosides. J Am Oil Chem Soc. 1984;61:1651-5.

60. Xu W, Osei-Prempeh G, Lema Herrera FC, Davis Oldham E, Aguilera RJ, Parkin S, Rankin SE, Knutson BL, Lehmler H-J. Synthesis, thermal properties and cytotoxicity evaluation of 
hydrocarbon and fluorocarbon alkyl $\beta$-D-xylopyranoside surfactants. Carbohydr Res. 2012;349:12-23.

61. Jurado E, Fernández-Serrano $M$, Núñez-Olea J, Luzón $G$, Lechuga M. Acute toxicity and relationship between metabolites and ecotoxicity during the biodegradation process of non-ionic surfactants: fatty-alcohol ethoxylates, nonylphenol polyethoxylate and alkylpolyglucosides. Water Sci Technol. 2009;59(12):2351-8.

62. Jurado E, Fernández-Serrano M, Núñez-Olea J, Lechuga M, Jiménez JL, Ríos F. Acute toxicity of alkylpolyglucosides to Vibrio fischeri, Daphnia magna and microalgae: a comparative study. Bull Environ Contam Toxicol. 2012;88(2):290-5.

63. Sahariah P, Benediktssdóttir BE, Hjálmarsdóttir MA, Sigurjonsson OE, Sørensen KK, Thygesen MB, Jensen KJ, Másson M. Impact of chain length on antibacterial activity and hemocompatibility of quaternary $\mathrm{N}$-alkyl and $\mathrm{N}, \mathrm{N}$-dialkyl chitosan derivatives. Biomacromolecules. 2015;16(5):1449-60.

64. Liu S, Guo C, Liang X, Wu F, Dang Z. Nonionic surfactants induced changes in cell characteristics and phenanthrene degradation ability of Sphingomonas sp. GY2B. Ecotoxicol Environ Saf. 2016;129:210-8.

65. Tobe S, Majima T, Tadenuma H, Suekuni T, Sakai K, Sakai H, Abe M. Nonionic surfactants enhancing bactericidal activity at their critical micelle concentrations. J Oleo Sci. 2015;64(1):61-8.

66. Fuchedzhieva N, Karakashev D, Angelidaki I. Anaerobic biodegradation of fluoranthene under methanogenic conditions in presence of surface-active compounds. J Hazard Mater. 2008;153(1-2):123-7.

67. Tian W, Yao J, Liu R, Zhu M, Wang F, Wu X, Liu H. Effect of natural and synthetic surfactants on crude oil biodegradation by indigenous strains. Ecotoxicol Environ Saf. 2016;129:171-9.

Wojciech Smułek, M.Sc. Eng. is a PhD student in the Institute of Chemical Technology and Engineering, Poznan University of Technology. His research area includes the impact of surfactants of natural origin on environmental bacteria.

Ewa Kaczorek, PhD, is an associate professor in the Institute of Chemical Technology and Engineering, Poznan University of Technology. Her research interests include the biodegradation of persistent organic pollutants and changes in bacteria cell surface properties during the biodegradation processes.

Zuzana Hricovíniová, PhD, is a research scientist in the Institute of Chemistry, Slovak Academy of Sciences. Her research focuses on the synthesis of saccharides and their derivatives, structure of molybdate complexes, and mechanisms of isomerization reactions catalyzed by transition metals. 